\title{
INSTRUMEN DISTRIBUSI DALAM EKONOMI ISLAM UNTUK MENINGKATKAN KESEJAHTERAN UMAT
}

\author{
Nandang Ihwanudin, Annisa Eka Rahayu \\ Universitas Islam Bandung \\ nandangihwanudin.ekis@gmail.com | annisaeka1397@gmail.com
}

\begin{abstract}
Economic growth can not be separated from the distribution of justice for each individual. But in reality, there appears to be injustice and inequality in the distribution of income and wealth, so that it has an impact on increasing the amount of poverty. Distribution policy in Islam upholds the values of justice based on the Koran, namely so that wealth does not circulate to only one group. To create the welfare of the people, it is needed an instrument in the distribution between: zakat, endowment, inheritance, donation and alms. it aims at income or wealth so as not to benefit parties who have capital and result in the accumulation of assets in certain groups. In addition, the public is required to realize the important role of creating fairness of distribution and narrowing economic inequality. If the distribution instruments can be implemented together, it is hoped that social security will form the welfare of the people.
\end{abstract}

Keywords: distribution; instruments; people's welfare

\begin{abstract}
Abstrak
Pertumbuhan ekonomi tidak terlepas dari keadilan distribusi bagi setiap individu. Namun pada realitanya, nampak terjadi ketidakadilan dan ketimpangan dalam pendistribusian pendapatan dan kekayaan, sehingga berdampak pada peningkatan jumlah kemiskinan. Kebijakan distribusi dalam Islam menjunjung tinggi nilai-nilai keadilan yang didasarkan pada al-Qur'an, yakni agar kekayaan tidak beredar hanya pada satu kelompok saja. Untuk menciptakan kesejahteraan umat maka diperlukan instrumen dalam distribusi diantara: zakat, wakaf, waris, infak dan sedekah. hal ini bertujuan pendapatan atau kekayaan agar tidak menguntungkan pihak yang bermodal dan berakibat pada penumpukan harta pada golongan tertentu. Selain itu, masyarakat dituntut untuk menyadari akan peran pentingnya menciptakan keadilan distribusi dan mempersempit kesenjangan ekonomi. Jika instrumen distribusi tersebut dapat diimplementasikan secara bersama-sama, diharapkan akan membentuk jaminan sosial yang akan menciptakan kesejahteraan umat.
\end{abstract}

Kata Kunci: distribusi; instrumen; kesejahteraan umat 


\section{A. Pendahuluan}

Pengalaman pembangunan ekonomi ${ }^{1}$ Indonesia sering menimbulkan permasalahan sosial di masyarakat, diantaranya adanya kesenjangan antara si kaya dan si miskin. Kesenjangan ini merupakan akibat dari tidak terciptanya distribusi yang adil di kalangan masyarakat. Ekonomi Indonesia yang "sosialistik" sampai 1966 berubah menjadi "kapitalistik" bersamaan dengan berakhirnya dengan Orde Lama (1959-1966). Sistem ekonomi dinyatakan berdasarkan pada Pancasila dan kekeluargaan yang mengacu pada Undang-undang Dasar 1945 Pasal 33 datang dalam praktiknya cenderung tidak demoktratis dan tidak adil.

Di saat masalah kemiskinan di Indonesia belum dapat diselesaikan, terjadi krisis keuangan global, yang mengakibatkan perekonomian mengalami gucangan cukup kuat dan dikhawatirkan akan berimbas pada ekonomi rakyat yang pada akhirnya akan menambah jumlah penduudk miskin di Indonesia. Oleh karenanya, berdasarkan pengalaman krisis yang lalu dan dalam menghadapi krisis yang akan datan tindakan utama yang harus dilakukan pemerintah adalah memperkuat ekonomi rakyat secara adil. Pendekatan kebijakan yang tidak memihak kepada rakyat diubah menjadi kebijakan yang pro tehadap rakyat, dengan jalan menciptakan suatu distribusi yang adil.

Distribusi $^{2}$ merupakan kegiatan menyalurkan suatu produk, barang, atau harta dari satu pihak ke pihak lain. Dalam Islam merupakan penyeluran harta yang ada, baik dimiliki oleh pribai atau umum (publik) kepada pihak yang berhak menerima yang ditujukan untuk meningkatkan kesejahteaan masyarakat sesuai dengan syariat. Prinsip utama dalam konsep distribusi adalah peningkatan dan pembagian bagi hasil kekayaan agar sirkulasi kekayaan dapat ditingkatka, shingga kekayaan yang ada dapat melimpah dengan merata dan tidak hanya beredar di antara tertentu saja. Titik berat dalam pemecahan permasalahan ekonomi adalah bagaimana menciptakan mekanisme distribusi ekonomi yang adil di tengah masyarakat. Distibusi dalam ekonomi Islam mempunyai makna yang lebih luas dan mencakup pegaturan kepemilikan, unsur-unsur produksi, dan sumber-smber kekayaan.

${ }^{1}$ Ruslan Abdul Gofur Noor, Konsep Distribusi dalam Ekonomi Islam: Dan Format Keadilan Ekonomi di Indonesia (Yogyakarta: Pustaka Pelajar, 2013), 5.

2 Ahmad Dahlan, Pengantar Ekonomi Islam (Jakarta: PrenadaMedia, 2019), 148. 
Dalam ekonomi Islam diatur kaidah pendaptan, baik antara unsur produksi maupun individu dan masyarakat dan anggota perserikatan maupun sidribusi sistem jaminan sosial. ${ }^{3}$

Islam memberikan batas-batas tertentu dalam berusaha, memiliki kekayaan dan mentransaksikannya. Dalam pendistribusian harta kekayaan al-Qur'an telah menetapkan langkahlangkah tertentu untuk mencapai pemerataan pembagian kekayaan dalam masyarakat secara objektif, seperti memperkenalkan hukum waris yan memberikan batas-batas kekuasaan bagi pemilik harta dengan maksud membagi semua harta kekayaan kepada semua karib kerabat apabila seseorang meninggal dunia. ${ }^{4}$ Begitupula dengan hukum zakat, infak dan sadaqah serta bentuk pemberian lainnya juga diatur untuk membagi kekayaan kepada masyarakat yang membutuhkan. Distribusi dalam bidang perdagangan juga disyariatkan dalam bentuk kerjasama , misalnya distribusi dalam akad mudhârabah merupakan bentuk distribusi kekayaan dengan sesama muslim dalam bentuk investasi yang berorientasi pada profit sharing. Pihak pemodal yang mempunyai kelebihan harta membantu orang yang punya keahlian berusaha, tetapi tidak punya modal. Tujuan aturan-aturan ini menurut Afzalur Rahman adalah untul pemutusan keayaan kepada golongan tertentu.

Baik distribusi ${ }^{5}$ pendapatan maupun kekayaan sangat berpengaruh terhadap kesejahteraan masyarakat. Hal ini bertujuan atas dasar tujuan Islam, yiatu ingin mensejahterakan kaumnya di dunia dan di akhirat. Dan ini akan bisa terealisasikan jikalau kebutuhan dasar (basic need) masyarakat bisa terpenuhi dengan baik. Sehingga, tidak ada kesenjangan antara si kaya dan si miskin. Pembahasan ini sesuai dengan prinsip maqasid alsyari'ah, yaitu merealisaskikan kemashlahatan diantara masyarakat dengan cara menghilangkan segala hal yang membawa pada kerusakan. Dengan terpenuhinya kebutuhan pokok setiap keluarga, maka akan biasa meminimalisasi segala macam kejahatan.

${ }^{3}$ Adiwarman Karim Ekonomi Makro Islam (Jakarta: PT. Raja Grafindo Persada, 2011), 155.

${ }^{4}$ Rozalinda, Ekonomi Islam: Teori dan Aplikasinya dalam Aktivitas Ekonomi (Jakarta: PT. RajaGrafindo Persada, 2016), 132.

${ }^{5}$ Ika Yunia Fauzia dan Abdul Kadir, Prinsip Dasar Ekonomi Islam: Perspektif Maqashid al-Syari'ah (Jakarta: Prenada Group, 2016), 140. 
Oleh karena itu, Islam berusaha keras untuk menegakkan distribusi yang adil di antara masyarakat, karena Allah sangat mengecam peredaran harta yang terkonsentrasi pada segelintir orang. Sebagaimana dalam firman-Nya dalam (Q.S. al-Hasyr (59): 7), yakni:

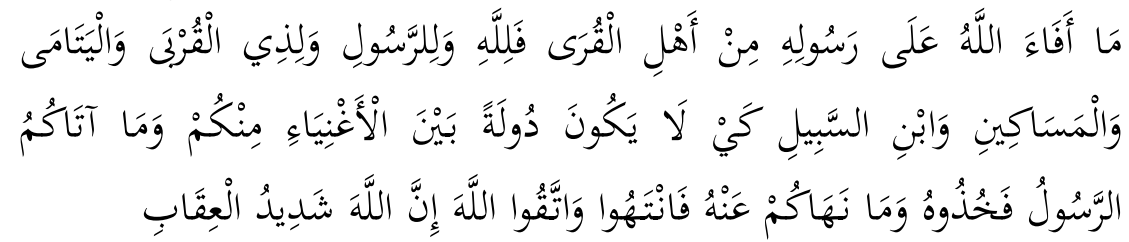

Artinya: "Apa saja harta rampasan (fai-i) yang diberikan Allah kepada Rasul-Nya yang berasal dari penduduk kota-kota maka adalah untuk Allah, Rasul, kerabat Rasul, anak-anak yatim, orang-orang miskin dan orang-orang yang dalam perjalanan, supaya harta itu jangan hanya beredar di antara orang-orang kaya saja di antara kamu. Apa yang diberikan Rasul kepadamu maka terimalah dia. Dan apa yang dilarangnya bagimu maka tinggalkanlah; dan bertakwalah kepada Allah. Sesungguhnya Allah sangat keras hukuman-Nya.

Namun sekarang ini muncul pemikiran sistem ekonomi sosialis dan kapitalis. Menurut sistem ekonomi sosialis, produksi tunduk pada pemerintah pusat. Segala sumber produksi adalah milik negara. Dasar distribusi barang ditetapkan oleh keputusan sidang di negar sosialis. Negaralah yang menyusun strategi produksi rakyat, juga menentukan garis-garis besar distribusi. Upah, gaji, bunga diatur oleh pemerintah. Di sisi lain, sistem ekonomi kapitalis, yang tiak pernah memperhatikan kebutuhan rakyat jelata yang miskin. Di bawah kekuasaan kapitalis monopoli yang meluas secara mengerikan. Kadang-kadang ditemukan satu perusahaan yang memiliki anyak anak cabang sehingga seperti negara dalam negara.

Namun, ekonomi Islam bebas dari tindak kapitalis dan sosialis. Islam merupakan filsafat dan tatanan yang berbeda dari keduanya. Islam memfokuskan perhatiannya pada distribusi sebelum membahas sektor produksi. Pemfokusan distribusi tidak berarti Islam tidak memperhatikan keuntungan yang diperoleh dari produksi. Islam mempraktikan distribusi secara adil melalui etika-etika yang tegas, sebagaimana Islam melarang segala bentuk riba. Dalam pembahasan kali ini, penulis akan memguraikan mengenai norma dan etika dalam distribusi agar tercptanya kejesahteraan ekonomi dikalangan umat sehingga tidak terjadi sistem ekonomi sosialis dan sistem kapitalis. 


\section{B. Konsep dan Prinsip Distribusi}

Distribusi merupakan bagian yang paling penting dalam membentuk kesejahteraan. Dampak dari distribusi pendapatan bukan saja pada aspek ekonomi, tetapi juga aspek sosial dan politik. Oleh karena itu Islam memberi perhatian terhadap distribusi pendapatan dalam masyarakat.

Pengertian distribusi menurut Kamus Besar Bahasa Indonesi (KBBI) adalah penyaluran (pembagian, pengiriman) kepada beberapa orang atau ke beberapa tempt: pembagian barang keperluan sehari-hari (terutama dalam masa darurat) oleh pemerintah kepada pegawai negeri, penduduk dsb. Sedangkan distribusi menurut para ahli produksi berupa barang dan jasa dri prosuden ke konsumen guna memenuhi kebutuhan manusia, baik primer maupun sekunder. ${ }^{6}$

Distribusi pendapatan dalam Islam merupakan penyaluran harta yang ada, baik dimiliki oleh pribadi atau umum (publik) kepada pihak yang berhak menerima yang ditujukka untuk meningkatkan kesejahteraan masyarakat sesuai dengan syariat Islam. Fokus dari distribusi pendapatan dalam Islam adalah proses pendistribusiannya. Secara sederhana bisa digambarkan, kewajiban menyisihkan sebagian harta bagi pihak surplus (berkecukupan) diyakini sebagai kompensasi atas kekayaannya dan di sisi lain merupakam intensif (perangsang) untuk kekayaan pihak defisit (berkekurangan). ${ }^{7}$

Baqir Sadr mengatakan distribusi pendapatan atau kekayaan berjalan pada dua tingkatan, yang pertama adalah distribusi sumber-sumber produksi dan yang kedua adalah distribusi pedapatan produktif. Pokok-pokok pikiran yang dimaksud Sadr, sebagai sumber-sumber produktif adalah terkait dengan tanah, bahan-bahan mentah, alat-alat dan mesin yang dibutuhkan untuk memproduksi beragam barang dan komoditas. Sedangkan yang termasuk dengan pendapatan atau kekayaan produktif hasil dari proses pengolahan atau hasil dari aktivitas produksi melalui kombinasi sumber-sumber produksi yang dihasilkan manusia melalui kerja.

${ }^{6}$ Sulaeman Jajuli, Ekonomi dalam al-Quran (Yogyakarta: Deepublish, 2017), 113.

7 Rozalinda, Ekonomi Islam: Teori dan Aplikasinya dalam Aktivitas Ekonomi (Jakarta: PT. RajaGrafindo Persada, 2016), 131. 
Berkenaan dengan ini pula, maka prinsip-prinsip menjaga adilnya sirkulasi kekayaan dan keseimbangan harta ditengahtengah kehidupan masyarakat juga masuk dalam konsepsi Baqir Sadr. ${ }^{8}$

Islam memberikan kebebasan kepada manusia untuk memiliki kekayaan, tetapi tidak memberikan begitu saja untuk memiliki semua apa yang dia suka, dan menggunakan cara apa saja yan mereka kehendaki. Kekayaan adalah suatu hal yang penting, tetapi yang lebih penting lagi adalah cara pedistribusiannya, karena jika distribusi kekayaan itu tidak tepat maka sebagian kekayaan itu beredar di antara orang kaya saja. Akibatnya banyak masyarakat yang menderita karena kemiskinan. Oleh karena itu, kesejahteraan rakyat tidak sepenuhnya tergantung pada hasil produsi, tetapi juga tergantung pada distribusi yang tepat. Seperti yang diumpamakan Afzalur Rahman, jika suatu negara mempunyai kelebihan kekayaan, tetapi distribsinya tidak berdasarkan pada prinsip keadilan dan kebenaran, maka negara itu belum dianggap berhasil. ${ }^{9}$ Begitu juga dengan kehidupan masyarakat modern yang mempunyai kekayaan yang melimpah, namun masih banyak masyarakat yang menderita kemiskinan. Hal ini disebabkan karena distribusi kekayaan yang belum merata.

Islam memberikan batas-batas tertentu dalam berusaha, memiliki kekayaan dan mentransaksikannya. Dalam pendistribusian harta kekayaan, al-Qur'an telah menetapkan langkah-langkah tertentu untuk mencapai pemerataan bagi kekayaan dalam masyarakat secara objektif, seperti mempeekenalkan hukum waris yang memeberikan batas kekuasaan bagi semua karib kerabat dengan maksud membagi harta kekayaan kepada semua karib kerabat bula seseorang meninggal dunia. Begitu pula dengan hukum zakat, infaq, sedekah, dan bentuk lainnya yang juga diatur untuk membagi kekayaan kepada masyarakat yang membutuhkan. Distribusi dalam dunia perdagangan juga disyariatkan dalam bentuk akad kerja sama, misalnya distribusi dalam bentuk mudhârabah merupakan bentuk distribusi kekayaan dengan semsama muslim dalam bentuk investasi yang berorientasi pada profit sharing.

${ }^{8}$ Muhamad, Sejarah Pemikiran Ekonomi Islam: Ekonomi, Manajemen, Keuangan, Bank dan Akuntansi (Yogyakarta: UII Press, 2019), 272.

${ }^{9}$ Soeroyo dan Nastangin, Doktrin Ekonomi Islam (Yogyakarta: Darma Bakti Wakaf, 1985), 92. 
Al-Qur'an berulang kali meningakan agar kaum Muslim tidak menyimpan atau menimun kekaaan yntuk kepentingan mereka sendiri, tetapi mereka harus memenuhi kewajiban terhadap keluarga, tetangga, dan orang-orang harus mendapat bantuan.

Fungsi distribusi dalam aktivitas ekonomi pada hakikatnya mempertemukan kepentingan konsumen dan prosuden dengan tujuan kemashlahatan umat. Aktivitas usaha distribusi ini kemudian ditunt untuk dapat memenuhi hak dan kewajiban yang diinginkan syariah bagi konsumen dan produsen.

\section{Ayat-ayat yang Berkaitan dengan Distribusi}

1) Distribusi Harta terdapat dalam QS. al-Hasyr (59):6

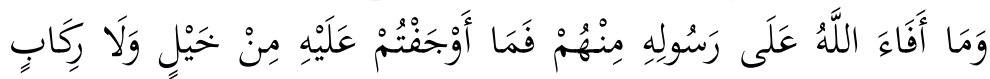

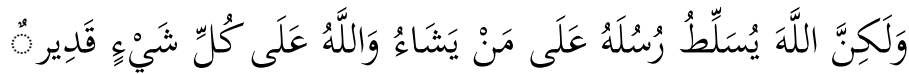
yang diberikan Allah kepada Rasul-Nya (dari harta benda) mereka, maka untuk mendapatkan itu kamu tidak mengerahkan seekor kuda pun dan (tidak pula) seekor unta pun, tetapi Allah yang memberikan kekuasaan kepada Rasul-Nya terhadap siapa yang dikehendaki-Nya. Dan Allah Maha Kuasa atas segala sesuatu."

Imam Ahmad meriwayatkan bahwa Umar r.a berkata "Rampasan perang dan kekayaan Bani Nadhir termasuk fai yang diberikan Allah kepada Rasul-Nya tanpa mengerahkan pasukan kuda atau barisan kendaraan unta karena itu khusus untuk Rasulullah Saw, sehingga Rasulullah Saw, mengambul dari sana bagian belanja untuk keluarganya dalam satu tahun dan sisanya untuk persiapan dan persenjataan kaum muslimin.

Kata $a f a$ 'ah terambil dari kata $f a$ ' $a$ dan $f a$ ' $i$ yang pada mulanya berarti kembali bayangan ketempat semula. Harta adalah milik Allah. Yang maha kuasa itu menghendaki agar harta diperoleh dan digunakan sesuai tuntunannya. ${ }^{10}$

${ }^{10}$ Quraish Shihab, Tafsir al-Misbah (Jakarta: Lentera Hati, 2003), 10. 
2) Prioritas Pendistribusian Harta, QS. al-Hasyr (59):7.

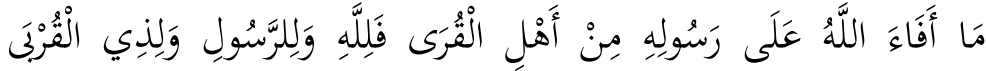

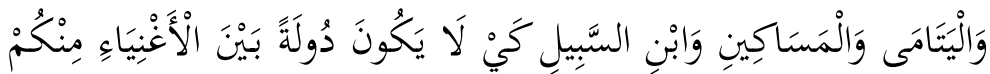

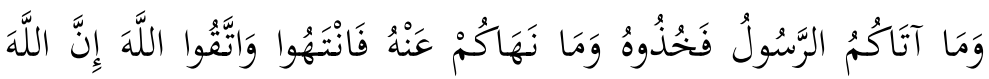

شَدَيدُ الْعِقَابِ

Artinya: "Apa saja harta rampasan (fai-i) yang diberikan Allah kepada Rasul-Nya yang berasal dari penduduk kota-kota maka adalah untuk Allah, Rasul, kerabat Rasul, anak-anak yatim, orang-orang miskin dan orang-orang yang dalam perjalanan, supaya harta itu jangan hanya beredar di antara orang-orang kaya saja di antara kamu. Apa yang diberikan Rasul kepadamu maka terimalah dia. Dan apa yang dilarangnya bagimu maka tinggalkanlah; dan bertakwalah kepada Allah. Sesungguhnya Allah sangat keras hukuman-Nya."

\section{Norma dan Etika dalam Distribusi}

Sebelum membahas moral dan etika, maka ada beberapa konsep yang dapat diimplementasikan dalam sistem pendistribusian, seperti dibawah ini.

Pertama, mengubah mindset (pola pikir) dan pembelajaran Islam, yang mulanya terfokus pada pemikiran dubiawi diubah menjadi pola pikir untuk kesejahteraan umat berbasis sumberdaya dan resiko yang berkeadilan, untuk mencapai kemanfaatan yang lebih besar.

Kedua, Hindari ketergantungan pada pihak lain. Hindari kebergantungan kepada orang lain, karena hanya Allah Swt yang memberikan keberkahan rezeki.

Setelah pola pikir diubah, maka ada beberapa norma dan etika dalam melaksanakan sistem distribusi. Distriusi ekonomi Islam terdiri dari dua sendi yaitu, sendi kebebasan dan sendi keadilan. $^{11}$

11 Yusuf Qardhawi, Norma dan Etika Ekonomi Islam (Jakarta: Gema Insani, 1997), 203. 
a) Konsep Kebebasan

Nilai yang utama dalam bidang distribusi kekayaan adalah kebebasan. Menurut Yusuf Qardhawi pembolehan dan pengakuan kepemilikan secara pribadi merupakan bukti dan jaminan pertama dari kebebasan yang ada dalam ekonomi Islam. Namun, sesungguhnya kebebasan yang disyariatkan Islam dalam ekonomi bukanlah kebebasan mutlak tanpa batas seperti yang terkendali. ${ }^{12}$

Nilai kebebasan dalam Islam memberi implikasi terhadap adanya pengakuan akan kepemilikan individu. Setiap hasil usaha seorang Muslim dapat menjadi miliknya menjadi motivasi yang kuat bagi dirinya untuk melakukan aktivitas ekonomi. Ia akan berusaha sekuat tenaga untuk mencari kekayaan. Kekayaan tidak akan ada artinya, kecuali denan memberikan pengakuan hak kepemilikannya. Dalam Islam, legitimasi hal milik sangat terkait erat dengan peran moral untuk menjamin keseimbangan. Hak milik pribadi diakui, dan hak kepemilikan itu harus berfungsi sebagi nafkah bagi sosial dan jihad fisabilillah.

Setiap individu, terus berusaha mencapai tingkat kemampuan materi. Akan tetapi, selalu ada pihak yang berkekurangan dan sebaliknya ada pihak yang berkelebihan. Kaya dan miskin adalah sunatullah. Harus dipahami, bahwa Islam tidakk menjadikan umat sebagai tujuan utama dari distribusi, dan pembangunan ekonomi. Namun demikian, upaya untuk mengeliminasi kesenjangan pendapatan umat adalah sebuah keharusan. Kewajiban untuk menyisihkan sebagian harta bagi pihak surplus (yang berkecukupan) merupakan insentif bagi pihak defisit (pihak yang berkekurangan Islam menawarkan konsep optimalisasi proses distribusi da redistribusi pendapatan. Konsep ini menuntut bantuan otoritas dari pemerintah (negeri) yang sangat bergantung pada ketaatan personal (rumah tangga) maupun masyarakat Muslim. ${ }^{13}$

12 Yusuf Qardhawi, Norma dan Etika Ekonomi Islam (Jakarta: Gema Insani, 1997), 319.

13 Rozalinda, Ekonomi Islam: Teori dan Aplikasinya dalam Aktivitas Ekonomi (Jakarta: PT. RajaGrafindo Persada, 2016), 136. 
b) Konsep Keadilan

Keadilan dalam Islam merupakan pondasi yang kokoh meliputi semua ajaran dan hukum Islam. Persoalan yang menjadi perhatian Islam dalam keadilan adalah pelarangan berbuat kezaliman. Ketidakseimbangan dsitribusi kekayaan adalah sumberdari semua konflik individu dan sosial. Untuk itu, agar kesejahteraan sosial dapat diwujudkn, penerapan prisip keadilan ekonomi merupakan suatu keharusan. Keadaan itu akan sulit dicapai bila tidak ada keyakinan dan penerapan prinsip moral tersebut. Di sinilah diperlukan pembumian etika ekonomi, menjadikan konsep moral sebagi fator endogen dalam perekonomian.

c) Larangan Riba dan Gharar

Secara khusus jika dihubungkan dengan masalah distribusi, maka riba dapat memengaruhi meningkatnya masalah dalam distribusi, yakni pertama, berhubungan dengan distribusi pendapatan bankir dan masyarakat secara umum, nasabah secara khsusu dalam kaitannya dengan bunga bank. Termasuk di dalamnya anyara investor dan penabung. Hal ini membuktikan bahwa Islam tidak menginginkan terjadinya eksploitasi sosial dalam berbagagi hungungan finansial yang tidak adil dan seimbang. ${ }^{14}$

Ketika pemilik modal (bank, pemilik modal dan lain-lain) dapat melakukan apa saja yang dikehendakinya, di antara mengambil keuntungan yang berlipat ganda untuk dirinya pada orang ain yang membutuhkan dana, maka tabpa disadari ketidakadilan dapat terjadi pada transaksi ini. Pihak yang membutuhkan dana untuk mencukupi kebutuhan kehidupannya maupun usahanya, namun tidak memiliki kemampuan finansial untuk emncukupinya. Eksploitasi dapat dengan mudah terjadi tanpa mempertimbangkan aspek moral dan keadilan, atau bahkan kompensasi apapun atas apa yang diminta pemilik modal pada pihak yang membutuhkan, sehngga akan berdampak pada tidak terciptanya hubungn kerja sama yang saling menguntungkan. Masalah kedua yang akan timbul yakni berhubungan dengan distribusi pendapatanantar berbagai kelompok masyarakat.

${ }^{14}$ Ruslan Abdul Gofur Noor, Konsep Distribusi dalam Ekonomi Islam: Dan Format Keadilan Ekonomi di Indonesia (Yogyakarta: Pustaka Pelajar, 2013),78. 
Para pekerja dan pemilik modal yang secara riil tidak bekerja, namun memilik dana maka dengan riba pemilik modal tersebut akan mendapat bagain secara pasti dan tetap, dari bekerjanya para pekerja tanpa harus ikut berpartisipasi dakan proses mencari keuntungan (produksi). Pemilik modal tidak secara jelas mengetahui seberapa besar keuntungan dan kerugian yang diperoleh dan harus ditanggung secara riil. Dilihat dari pengertin lain, pemilik modal yang tidak berpartisipai dalam proses produksi dapat dikategorikan sebagai pengangguran terselubung karena ia tidak mendapatkan pendapatan karena ia bekerja, namun mendapat pendapatan karena orang lain dan modal hartanya yang bekerja.

Begitupula dengan larangan gharar dalam Islam, yang sering diartikan sebagai "ketidakpastian"dalam transaksi. Islam melarng seseorang bertransasksi atau satu barang yang kualitasnya tidak diketahui karena keda belah pihak tidak tahu apa yang ditransaksikan. Gharar terjadi karena seseorang sama sekali tidak dapat mengetahui kemungkinan kejadian sesuaru sehingga bersifat perjudian (spekulasi) atau terjadi kurangnya informasi. Islam mengajarkan aktivitas ekonomi yang saling menguntungkan dan bukan mencari keuntungan atas kerugian orang lain, sehingga berbagai bentuk hubungan transaksi yang mengandung gharar tidak diperkenankandalam Islam. Di samping itu, gharar secara langsung akan menghabat terciptanya pasar yang adil, dan menghambat terciptanya distribusi yang adil, d) Larangan Menimbun Harta

Islam membenarkan hak milik pribadi, namun tidak membenarkan penumpukan harta, benda pribadi sampai batasbatas yang dapat merusak fondasi sosial Islam, karena penumpukan harta berlebihan bertentangan dengan kepentingan umum, yang berimbas pada rusaknya sistem sosial dengan munculnya kelas-kelas yang mementingkan kepentingan pribadi. Di samping itu, penumpukan harta berlebihan dapat melemahan daya beli masyarakat dan menghambat mekanisme pasar bekerja secara adil, karena harta tidak tersebar di masyarakat.

Apabila terjadi demikian, dibenarkan bagi pemeritah dengan kekuasannya untuk mengambil secara paksa harta tersebut demi kpentingan asyarakat melalui intrumen zakat. Kebijakan untuk membatasi harta pribadi daoat dibenarkan dan dilakukan demi menjamin terciptanya kondisi sosial yang sehat dan terwujudnya andasan keadilan distribusi. 


\section{E. Instrumen Distribusi dala Ekonomi Islam untuk Meningkatkan Kesejahteraan Umat.}

a) Zakat sebagai Model Distribusi Wajib Individu

Kesadaran untuk menunaikan kewajiban zakat bagi setiap muslim merupakan ata kunci bagi terciptanya umat yang sejahtera. Hal ini karena kewajiban membayar zakat merupakan poros utama dalam sistem keuangan Islam (fiskal) dan sejalan dengan prisnip distribusi dalam ISlam agar harta tersebar pada seluruh rakyat.

Zakat juga berbeda dengan pajak karena dalam perspektif ekonomi Islam zakat memiliki dasar, pemahaman dan teori hukum syar'i yang bersumber dari al-Qur'an dan asSunnah yang sangat berbeda dengan pajak. Kesamaan antara zakat dan pajak adalah dalam bentuknya, bukan kesamaan yang hakiki seperti halnya;

\begin{tabular}{|c|c|c|c|}
\hline \multicolumn{2}{|r|}{ Zakat } & \multicolumn{2}{|r|}{ Pajak } \\
\hline \multirow[b]{2}{*}{1} & Harta & \multirow[b]{2}{*}{1} & Harta \\
\hline & $\begin{array}{l}\text { harta tunai maupun } \\
\text { barang } \quad \text { berdasarkan } \\
\text { prisnip pemerataan. }\end{array}$ & & Harta Tunai \\
\hline \multirow[b]{2}{*}{2} & Kewajiban & \multirow[b]{2}{*}{2} & Kewajiban \\
\hline & $\begin{array}{ll}\text { Kewajiban } & \text { terhadap } \\
\text { hukum Syar'i } & \\
\end{array}$ & & $\begin{array}{l}\text { Kewajiban terhadap } \\
\text { hukum pemerintah }\end{array}$ \\
\hline \multirow[b]{2}{*}{3} & Kewajiban final & \multirow[b]{2}{*}{3} & Kewajiban final \\
\hline & $\begin{array}{lr}\text { mendapat } & \text { pahala, } \\
\text { kemashlahatan } & \text { umat, } \\
\text { mencapai fallah } & \\
\end{array}$ & & $\begin{array}{l}\text { Kesejahteraan } \\
\text { masyarakat }\end{array}$ \\
\hline \multirow{2}{*}{4} & Ukuran & \multirow[t]{2}{*}{4} & Ukuran \\
\hline & Sesuai dengan nisab & & Ditentukan pemerintah \\
\hline
\end{tabular}

Menurut Masdar Darid Mas'udi yang menyatukan zakat sebagai pajak karena penagannaya dilakukan pemerintah sebagai sumber pemasukan negara. Namun, di sisi lain zakat sebagai rukun Iskam yang ditentulan langsung oleh al-Qur'an untuk siapa dan untuk keperluan apa, sehingga dalam menanganinya dituntut sikap ekstra hati-hati. 
Kewajiban zakat secara tegas telah tertulis dalam QS. at-Taubah (9): 103, yakni:

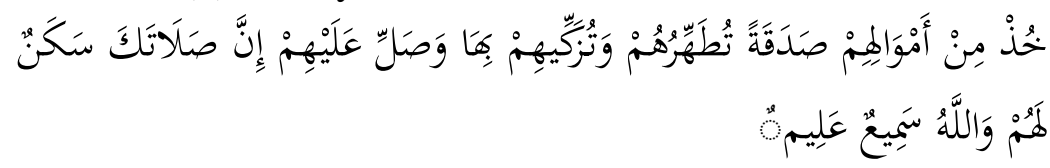

Artinya: "Ambillah zakat dari sebagian harta mereka, dengan zakat itu kamu membersihkan dan mensucikan mereka, dan mendoalah untuk mereka. Sesungguhnya doa kamu itu (menjadi) ketenteraman jiwa bagi mereka. Dan Allah Maha Mendengar lagi Maha Mengetahui."

Zakat sejalan dengan prisnip utama tentang distribusi dalam ajaran Islam "agar harta tidak hanya beredar dikalangan orang-orang kaya di antara kamu", prinsip tersbut dijadikan aturan main yangharus dijalankan karena jika diabaikan, akan menimbulkan jurang yang dalam antara si kaya dan si miskin, serta tidak terciptanya keadilan di masyarakat. Zakat diwajibkan atas setiap orang Islam yang merdeka, dewasa, berakal dan memiliki arta satu nisab penuh. Sedangkan harta yang wajib dikeluarkan zakatnya ialah harta yang dapat dikembangkan dan bukan harta yang digunakan untuk mencukupi kebutuhan, meskipun harta tersebut saat ini belum dikembangkan.

Harta yang dizakati harus memenuhi beberapa syarat yakni: pertama, harta tersebut merupakan miliknya oebuh da telah sampau pada batas minimal (nisab), minimal untuk barang komoditas diperkirakan seharga 20 dinar emas atau berkisar 96 gram emas. Kedua, harta mencapai nisab dalam satu tahun setelah digunakan untuk memenuhi kebutuhan pokok seperti tempat tinggal, makanan, pakaian.

Untuk harta yang telah mencapai nisab dan haul, namun sedang tidak berada di tangan atau dituangkan, maka zakat tetap wajib dikeluarkan meskipun terdapat perbedaan di antara ulama mazhab. ${ }^{15}$

\footnotetext{
${ }^{15}$ Mazhab Hanafi berpendapat bahwa untuk utang kuat (qawiy) atau utang atas barabf perdagangan jika diakui oleh penghtangnya atau ada bukti yang menguatkan maka ia wajib mengeluaran zakat setelah harta tersebut berada di tangan pemiliknya. Untuk utang menengah (mutawait) utang yang bukan perdagangan seperti utang rumah, maka tidak ada kewajiban zakat kecuali pemilik telah menerimanya kembali dan telah mencapai nisab. Sedangkan utang ringan ( $d a^{\prime}$ if $)$ utang bukan berupa harta, seperti mahar, waris, wakaf, bayaran hulul, maka utang ini tidak wajib dizakati kecuali penrimanya telah menerima sampai pada nasab dan haul.
} 
Dari perbedaan pendapat tersebut dapat diambil satu persamaan bahwa harta utang yang diakui oleh penghutangnya maka wajib dizakati. Untuk utang yang tidak bisa dilunasi maka tidak ada kewajiban zakat atasya.

Pada masa Rasul, harta yang dapat dikembangkan serta wajib zakat meliputi:

1) Binatang ternak, apabila dipelihara untuk perkembangbiakan dan bukan untuk dipekerjakan,

2) Emas dan perak, dahulu dijadikan mata uang. Untuk emas dan perak sebesar 2,5\% dari nisabnya (20 dinar dama dengan 96 gram emas dan 200 dirham atau sama dengan lebih kurang 672 gram perak). Sebagian besar ulama berpendapat bahwa uang kertas yang saat ini digunakan sebagai pengganti emas dan perak juga wajib dizakati meskipun hanya sebagai simpanan.

3) Barang dagangan (perniagaan), nisabnya 96 gram emas dan zakatnya $2,5 \%$ apabila terpenuhi selama setahun.

4) Hasil bercocok tanam termasuk di dalamnya makanan pokok seperti kurma, gandum, padi dan bahan pokok lainnya sesuai dengan keadaan di daerah masing-msing. Serta buah-buahan, maka jumhur ulama berpendapat bahwa untuk apa yang dihasilkan di bumi dab apa yang dibuahkan oleh pepohonan tidak memiliki nisab tertentudan tidak disyaratkan melewati setahun tetapi diwajibkan zakat ketika panen. Yaitu $10 \%$ untuk lahan yang tanpa irigasi dan 5\% untuk yang menggunakan irigasi.

Harta kekayaan berupa bangunan, pabrik, kapal, pesawat dan sebagainya tidak wajib dikeluarkan zakatnya, yang diambil dari benda tersebut, namun keuntungan bersihnya jika telah mencapai nisab wajib dikeluarkan zakatnya. Begitu juga dengan zakat profesi baik wiraswasta maupun pegawai negeri wajib mengeluarkan zakat dari penghasilannya begitu diterima, meskipun belum mencapai satu tahun. hal ini sesuai dengan pendapat Ibn Abbas, Ibn Mas'ud, dan Mu'awiyah, sebagian tabiin az-Zuhrim Hasan Basri, sehingga tercipta kesamaan antara zakat profesional dan petani yang dikeluarkan ketika panen. 
Di samping kewajiban untuk mengambil zakat yang telah ditetapkan, pendistribusian dana zakat pun dalam Islam tercantum dengan jelas. Sebagaimana yang tertuang dalam Q.S. at-Taubah (9): 60.

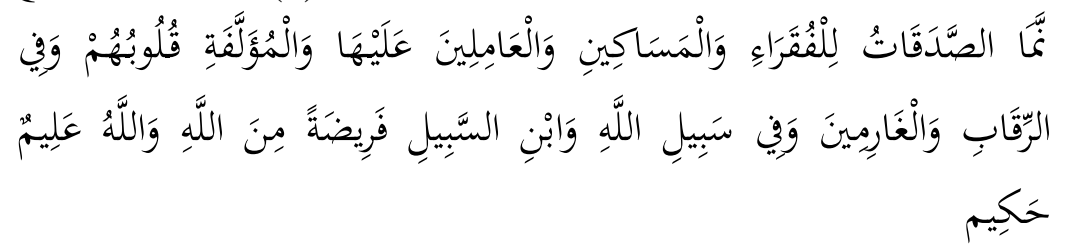

Artinya: "Sesungguhnya zakat-zakat itu, hanyalah untuk orang-orang fakir, orang-orang miskin, penguruspengurus zakat, para muallaf yang dibujuk hatinya, untuk (memerdekakan) budak, orang-orang yang berutang, untuk jalan Allah dan orang-orang yang sedang dalam perjalanan, sebagai sesuatu ketetapan yang diwajibkan Allah; dan Allah Maha Mengetahui lagi Maha Bijaksana."

Pendistribusian dana zakat kepada para mustahîk dapat dalam bentuk konsumtif ataupun produktif. Zakat secara konsumtif sesuai sasaran apabila pendayagunaannya adalah fakir dan miskin yang memerlukan makanan dengan segera. apabila fakir dan miskin diberikan zakat produktif maka harta zakat akan cepat habis. namun, setelah kebutuhan tersebut tercukupi maka dana zakat dapat dipergunakan untuk membekali mereka dengan keterampilan (skill) dan modal kerja, sehingga dapat membuka lapangan pekerjaan baru yang secara ekonomi memberikan nilai tambah dan dapat menyerap mereka. ${ }^{16}$

Penghasilan yang diperoleh dari kerja tersebut, dapat mencukupi kebutuhan sehari-hari mereka dalam jangka panjang. dengan demikan jumlah dana yang didistribusikan harus berbeda-beda sesuai dengan tempat, waktu, jenis usaha dan sifat penerimaan zakat.

\footnotetext{
${ }^{16}$ Imam Abu Hanifah, membolehkan mengganti zakat dengan harganya (uang tunai).
} 
Pendistribusian zakat saat ini dapat diberikan pada beberapa golongan sebagai berikut. ${ }^{17}$

a) Bagi Fakir dan miskin, jika memiliki potensi usaha makan dana zakat dapat diberikan untuk:

1) pinjaman modal usaha agar usaha yang ada dapat berkembang.

2) membangun sarana pertanian dan perindustrian untuk mereka yang tidak mendapatkan pekerjaan.

3) membangun sarana-sarana pendidikan dan pelatihan untuk mendidik mereka agar terampil dan terentas dari kemiskinan.

b) Zakat bagi amil dialokasikan untuk:

1) menutupi biaya administrasi dan memberikan gaji bagi amil yang telah mengabdkan hidupnua untuk kepentingan umat.

2) mengembangkan lembaga-lembaga zakat dan melatih amil agar lebih prfesional.

c) Zakat bagi golongan muallaf:

1) membantu kehidupan muallaf karena kemungkinan mereka mengalami kesulitan ekonomi karena berpndah gama.

2) menyediakan sarana dan dana untuk membantu orangorang yang terjebak pada tindakan kejaatan, asusila dan obat-obatan terlarang.

3) membantu terciptanya sarana reabilitasi kaemanusian lainnya.

d) Zakat bagi golongan budak (riqab):

1) membebaskan masyarakat muslim yang tertindas seingga sulit untuk mengembangkan diri terutama di daerah-daerah minoritas dan konflik.

2) membantu membebaskan buruh-buruh dari majikan yang zalim, dalam hal ini membantu dalam biaya maupun mendirikan lembaga advokasi para TKI/TKW yang menjadi korban kekerasan.

3) membantu membebaskan mereka yang menjadi korban traficking.

${ }^{17}$ Abdurrahman Qadir, Zakat dalam Dimensi Mahdah dan Sosial (Jakarta: Raja Grafindo Persada, 1998), 159. 
e) Zakat bagi gharimin (orang yang berutang):

1) membebaskan utang orang yang terlilit utang oleh rentenir.

2) membebaskan para pedagang dari utang modal pada bank tilil di pasar-pasar tradisional.

f) Zakat bagi golongan fisabilillah:

1) membantu pembiayaan dalam meningkatkan kualitas sumber daya manusia.

2) membantu para guru agama/umum yang ada di daerah-daerah terpencil dengan penghasilan yang minus.

3) membantu pembiayaan pemerintah dalam mempertahankan kedaulatan dari gangguan asing.

g) Zakat untuk golongan ibn sabil:

1) membantu pada pelajar/mahasiswa yang tidak mampu untuk membiayai pendidikannya.

2) menyediakan bantuan bagi korban bencana alam dan bencana lainnya.

3) menyediakan dana bagi para musafir yang kehabisan bekal.

Sesungguhnya kesadaran umat Islam akan kewajiban zakat yang memiliki banyak dimensi di antaraya sosial, moral dan ekonomi yangakan berimabas pada meningkatnya zakat yang dikeluarkan dan menciptakan kesejahteraan umat.

b) Wakaf sebagai Instrumen Distribusi Individu untuk Masyarakat

Menurut istilah wakaf diartikan sebagai suatu pemberian yang dilakukan dengan cara menahan (kepemilikan) untuk dimanfaatkan guna kepentingan umum. Ajaran wakaf bersumber pada pemahaman akan teks alQur'an dan hadits. Secara khusus tidak ditemukan dalam alQur'an ayat yang tegas menjelaskan tentang wakaf, namun yang ada ialah pemahaman konseptual dari ayatbyang menganjurkan untuk melakukan amal kebajukan (sunnah) agar mendapatkan kemenangan. 
Berdasarkan pengertian dan landasan hukum wakaf tersebut, dapat dipahami bahwa harta wakaf sepenuhnya, digunakan untuk kemashlahatan umat dan pada harta wakaf kecuali untuk kemashlahatan umat. Wakaf pada dasarnya sejalan dengan tujuan ekonomi modern, menjadi cara yang lebih baik untuk mendistribusikan pendapatan di masyarakat dengan memberikansolusi terhadap pemenuhan kebutuhan publik. Hal ini dapat dilakukan dengan memanfaatkan wakaf bagi kepentingan masyarakat luas, seperti halnya penggunaan dana wakaf untuk menyediakan air bersih, mendukung terciptana institusi pendidikan, riset dan perpustakaan yang akan membantu perkembangan kualitas sumber daya manusia.

Penggunaan dana wakaf untuk kepentingan mesayarakat atau umat dilihat dari keberadaan harta wakaf yang digunakan untuk pendidikan, ekonomi, dan kegiatan sosial sebagaimana yang banyak dilakukan di negara Muslim seperti Mesir, Turki, Arab Saudi, Qatar, Malaysia dan masih banyak lagi. contoh riil pemanfaatan harta wakaf terlihat pada sekitar Masjid Nabawi dan Masjidil Haram yang merupakan tanah wakaf. kemudian Universitas Islam Indonesia yang merupakan tanah wakaf pada awalnya.

Di samping beberapa contoh di atas, secara ekonomi pemberdayaan harta wakaf juga dapat dilakukan untuk meningkatkan keterampilan umat. hal ini dapat dilakukan engan memdikirkan lebaga-lembaga keuangan mikro, lembaga pendidikan, lembaga rumah sakit dan lain sebagainya, yang sepenuhnya untuk meningkatkan kemampuan umat agar dapat bersaing pada lapangan kerja dan terentas dari kemiskinan. 
c) Waris sebagai Instrumen Distribusi dalam Keluarga

Lahirnya konsep waris dipresentasikan oleh teks alQur'an yang rinci, dan sistematis yang menempai posisi fundamental dalam ajaran Islam. hal ini dapat dibuktikan dengan penjelasan dasar-dasar sistem kewarisan Islam pada ayat-ayat dalam al-Quran sebagaimana yang terdapat dalam QS. an-Nisa (4): 11-12, yakni:

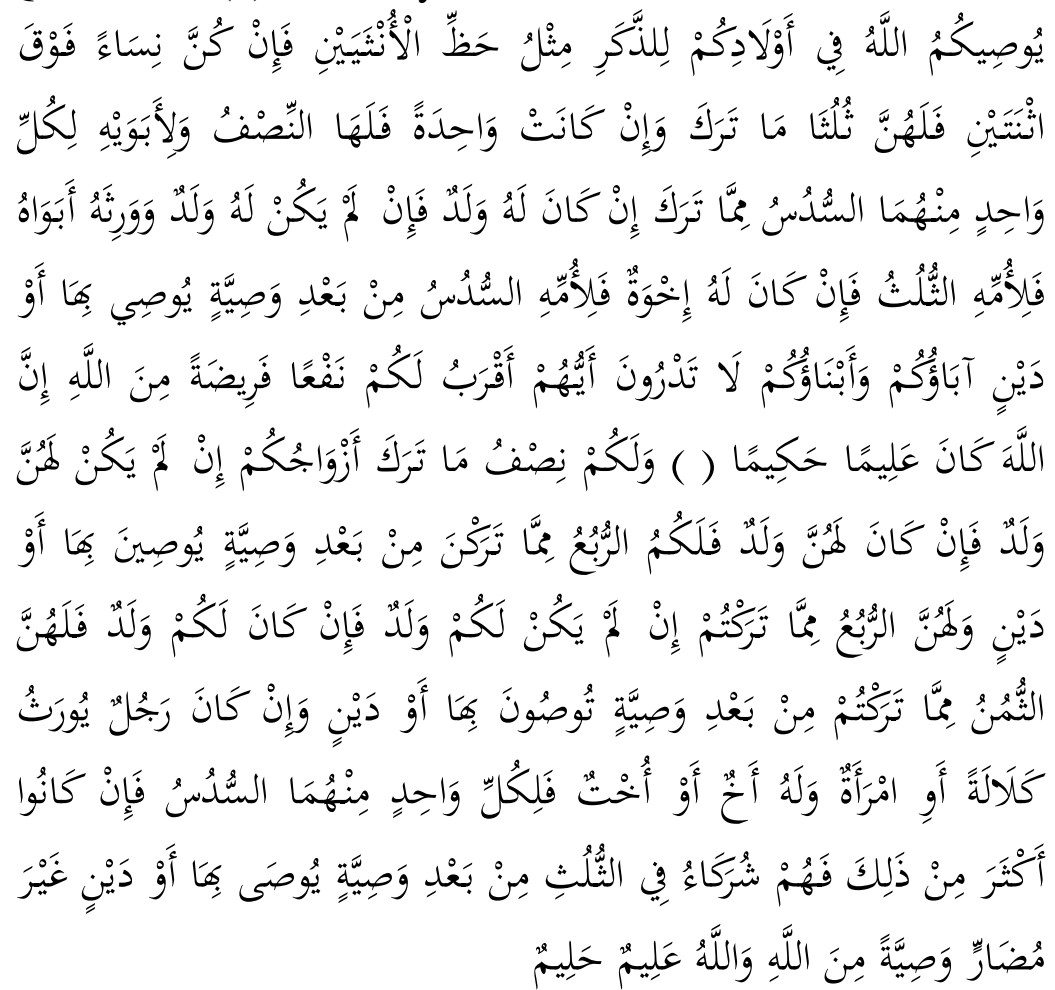

Artinya: "Allah mensyariatkan bagimu tentang (pembagian pusaka untuk) anak-anakmu. Yaitu: bahagian seorang anak lelaki sama dengan bahagian dua orang anak perempuan; dan jika anak itu semuanya perempuan lebih dari dua, maka bagi mereka dua pertiga dari harta yang ditinggalkan; jika anak perempuan itu seorang saja, maka ia memperoleh separo harta. Dan untuk dua orang ibu-bapak, bagi masing-masingnya seperenam dari harta yang ditinggalkan, jika yang meninggal itu mempunyai anak; jika orang yang meninggal tidak mempunyai anak dan ia diwarisi oleh ibu-bapaknya (saja), maka ibunya mendapat sepertiga; jika yang meninggal itu mempunyai beberapa saudara, maka ibunya mendapat seperenam. (Pembagian-pembagian tersebut di atas) sesudah dipenuhi wasiat yang ia buat atau 
(dan) sesudah dibayar utangnya. (Tentang) orang tuamu dan anak-anakmu, kamu tidak mengetahui siapa di antara mereka yang lebih dekat (banyak) manfaatnya bagimu. Ini adalah ketetapan dari Allah. Sesungguhnya Allah Maha Mengetahui lagi Maha Bijaksana. Dan bagimu (suami-suami) seperdua dari harta yang ditinggalkan oleh istri-istrimu, jika mereka tidak mempunyai anak. Jika istri-istrimu itu mempunyai anak, maka kamu mendapat seperempat dari harta yang ditinggalkannya sesudah dipenuhi wasiat yang mereka buat atau (dan) sesudah dibayar utangnya. Para istri memperoleh seperempat harta yang kamu tinggalkan jika kamu tidak mempunyai anak. Jika kamu mempunyai anak, maka para istri memperoleh seperdelapan dari harta yang kamu tinggalkan sesudah dipenuhi wasiat yang kamu buat atau (dan) sesudah dibayar utang-utangmu. Jika seseorang mati, baik laki-laki maupun perempuan yang tidak meninggalkan ayah dan tidak meninggalkan anak, tetapi mempunyai seorang saudara laki-laki (seibu saja) atau seorang saudara perempuan (seibu saja), maka bagi masing-masing dari kedua jenis saudara itu seperenam harta. Tetapi jika saudara-saudara seibu itu lebih dari seorang, maka mereka bersekutu dalam yang sepertiga itu, sesudah dipenuhi wasiat yang dibuat olehnya atau sesudah dibayar hutangnya dengan tidak memberi mudarat (kepada ahli waris). (Allah menetapkan yang demikian itu sebagai) syariat yang benarbenar dari Allah, dan Allah Maha Mengetahui lagi Maha Penyantun."

Meskipun ayat tersebut secara umum menjelaskan tentang kewarisan Islam, namun pada kalangan tertentu hukum kewarisan Islam bisa saja ditafsirkan dan direkonstruksi sesuai dengan kondisi yang memungkinkan untuk dipertimbangkan, terkecuali masa berlakunya hukum waris yang disebabkan oleh kematian seseorang, jika ia meninggalkan sejumlah harta dan memilik ahli waris tanpa adanya penunjukan sebelum ketika ia hiup, tanpa adanya transaksi amal tertentu kepada orang lain. ${ }^{18}$

${ }^{18}$ Penjelasan siapa-siapa ahli waris disebutkan dalam QS. an-Nisa (4):11- 
Dari fakta sejarah terbentuknya konsep waris Islam, dapat dianalisis bahwa waris dalam Islam erat kaitannya dengan distribusi kekayaan dalam keluarga, terutama agar terciptan keadilan dalam pembagian harta waris. Hal ini tidak terlepas dari konsep Islam bahwa harta harus tersebar di masyarakat bukan terkumpul pada satu dua orang saja. Konsep waris Islam merupakan mekanisme diatribusi kekayaan dan jaminan sosial riil dalam keluarga. Terlepas dari perbedaan penafsiran dalam ranah hukum, pembagian harta waris dalam keluarga secara ekonomi dapat membantu dalam menciptakan distribusi kekayaan secara adil dan mampu membantu mengurangi kesenjangan dalam distribusi kekayaan. ${ }^{19}$ Membagikan harta waris kepada ahli waris yang berhak baik disebabkan oleh hubungan perkawinan, kekerabatan maupun perwalian, secara langsung telah menciptakan jaminan sosial dalam keluarga, agar diantara anggota keluarga tidak terjadi ketimpangan dalam memperoleh kekayaan.

Distribusi kekayaan secara adil berdasarkan konsep waris dalam keluarga, dapat memotivasi pewaris untuk semasa hidupnya mencari rezeki yang sebesar-besarnya agar tidak meninggalkan keturunan yang lemah. Ahli waris dengan harta waris dapat mencukupi kebutihan sosio-ekonominya di saat pewaris telah meninggal dunia, serta harta waris digunakan untuk biaya pendidikan, hidup, usaha dan menanggung keluarga.

Secara langsung pewaris tidak emninggalkan anakanak (yatim piatu) yang msikin dan terbelakang karena pewaris tidak meninggalkan harta waris yang cukup untuk kehidupan mereka. begitupula ahli waris untuk menjaga dirinya agar tidak melakukan hal-hal yang dapat menyebabkan terputusnya hak waris yang dimiliki. ${ }^{20}$

${ }^{19}$ M. Umer Chapra, Islam dan Pembangunan Ekonomi (Jakarta: Gema Insani Press, 2000), 109.

${ }^{20}$ Para ulama sepakat bahwa status seseorang karena perbedaan agama, sesbab membunuh dan perbudakan merupakan penghalang terjadinya perwarisan. 
d) Infak dan Sedekah sebagai Instrumen Distribusi Umat

Sedekah merupakan pemberian dari seorang muslim secara sukarela tanpa dibatasi oleh waktu dan jumlah tertentu, atau suatu pemberian yang dilakukan oleh seseorang sebagai kebajikan yang mengharap ridha Allah Swt, dan pahala semata. ${ }^{21}$ Penekanan terhadap sikap berinfak dan bersedekah merupakan sarana yang tepat untuk membantu menciptakan masyarakat yang peduli akan kondisi sosial, karena pada dasarnya setiap manusia harus menyadari bahwa setiap indivisu tidak dapat hisup sendiir, dan sebalikanya membutuhkan orang lain. infak dan sedekah keahlian dapt dilakukan dengan melihat profesi individu dan menyumbangkan kahliannya dalam satu wadah atau lembaga yag dikelula secara bersama-sama dan didirikan dari harta wakaf. seperti halnya lembaga pendidikan SD/MI, SMP/MTS, SMA/MA bahkan perguruan tinggi (PT) bagi mereka yang berprofes menjadi guru atau dosen, denga meluangkan sedikit waktu untuk mengajar.

Rekonstruksi infak dan sedekah profesi tersebut, secara langsung dapat meningkatkan kemanfaatan lebih besar dari sekadar infak dan sedekah yang biasa diakukan, serta mewujudkan jaminan akan terciptanya masyarakat yang lebih baik, serta terselenggaranya pendidikan, kesehatan, hukum dan segalanya secara gratis dan berkesinambungan.

Sesungguhnya jika dicermati lebih jauh keberadaan instrumen distribusi dalam sistem ekonomi Islam, maka akan membentuk satu mekanisme jaminan sosial yang menyeluruh, bukan hanya untuk kebutuhan pokok masyaraka namun lebih dari itu dengan instrumen-instrumen yang ada mampu menciptakan masyarakat yang sejahtera.

${ }^{21}$ Ensiklopedi Hukum Islam (Jakarta: Ichtiar Baru Van Hoeven, 2001), 1617. 


\section{F. Penutup}

Sistem ekonomi Islam mewajibakan peran pemerintah dan masyarakat sebagai institusi distribusi dalam mewujudkan keadilan distribusi, karena menciptakan kesejahteraan merupakan kewajiban seluruh agen ekonomi sebagai konsekuensi dari tugasnya umat sebagai khalifah Allah Swt di muka bumi untuk menciptakan instrumen distribusi yang ditawarkan Sistem Ekonomi Islam berupa Zakat sebagai instrumen distribusi wajib bagi indivisu, apabila dikelola dengan baik dan profesional maka para mustahik (8 asnaf) yang terdapat di dalamnya akan mendapatkan bagian yang cukup untuk kehidupannya sehingga dengan zakat tercipta jaminan sosial. Begitu juga dengan Instrumen waris yang wajib individu atas keluarga, akan membentuk jaminan sosial individu untuk keluarga.

Setiap individu akan termotivasi untuk bekerja keras agar nantinya tidak meninggalkan generasi yang lemah. Kemudian pada instrumen wakaf, apabila wakaf dikelola dengan baik maka akan menjadi jaminan sosial bagi seluruh umat yang dapat memberi kemanfaatan sebesar-besarnya untuk kepentingan umat. Dan yang terkahir instrumen infak dan sedekah sebagai amal kebajikan individu terhadap umat, akan mendukung terciptanya para profesional yang ikhlas. Sinergi instrumen distribusi di atas akan menciptakan jaminan sosial yang menyeluruh bagi segenap umat. Jika instrumen tersebut dapat diimplementasikan dan bergerak secara bersama-sama, diharapkan akan membetuk jaminan sosial yang akan menciptakan kesejahteraan umat. 


\section{Daftar Pustaka}

Dahlan, Ahmad, Pengantar Ekonomi Islam, Jakarta: Prenada Media, 2019.

Ensiklopedi Hukum Islam, Jakarta: Ichtiar Baru Van Hoeven, 2001.

Fauzia, Ika Yunia dan Abdul Kadir, Prinsip Dasar Ekonomi Islam: Perspektif al-Syari'ah, Jakarta: Prenada Group, 2014.

Jajuli, Sulaeman, Ekonomi dalam Al-Quran, Yogyakarta: Deepublish, 2017.

Karim, Adiwarman, Ekonomi Makro Islam, Jakarta: PT. Raja Grafindo Persada, 2011, 155.

Majid, M. Nazori, Pemikiran Ekonomi Abu Yusuf. Yogyakarta: Pusat Studi Ekonomi Islam, 2003.

Muhamad, Sejarah Pemikiran Ekonomi Islam: Ekonomi, Manajemen, Keuangan, Bank dan Akuntansi, Yogyakarta: UII Press, 2019.

Noor, Ruslan Abdul Gofur, Konsep Distribusi dalam Ekonomi Islam: Dan Format Keadilan Ekonomi di Indonesia, Yogyakarta: Pustaka Pelajar, 2013.

Rozalinda, Ekonomi Islam: Teori dan Aplikasinya dalam Aktivitas Ekonomi,akarta: PT. RajaGrafindo Persada, 2016.

Shihab, M. Quraish, Tafsir al-Misbah, Jakarta: Lentera Hati, 2002.

Soeroyo dan Nastangin, Doktrin Ekonomi Islam, Yogyakarta: Darma Bakti Wakaf, 1985.

Umer, M Chapra, Islam dan Pembangunan Ekonomi, Jakarta: Gema Insani Press, 2000.

Qadir, Abdurrahman, Zakat dalamDimensi Mahdah dan Sosial, Jakarta: Raja Grafindo Persada, 1998.

Qardhawi, Yusuf, Norma dan Etika Ekonomi Islam, Jakarta: Gema, 1997. 